\title{
Implementasi manajemen kesiswaan pada sekolah bertaraf internasional
}

\author{
Yelis Nurwahidah a,1, ${ }^{\text {, }}$, Tasya Lestari a,2, Kisra Wahab a,3 \\ a Sekolah Tinggi Ilmu Tarbiyah Madani Yogyakarta, Yogyakarta, Indonesia; \\ *1yelisnurwahidah@gmail.com; ${ }^{2}$ lestaritasya@gmail.com; ${ }^{3}$ wahabkikis@gmail.com
}

KATAKUNCI

Manajemen

Kesiswaan

Sekolah Bertaraf Internasional
KEYWORDS

Management

Student

International Standard School

\section{ABSTRAK}

Penelitian ini bertujuan untuk mengetahui pelaksanaan manajemen kesiswaan pada Sekolah Bertaraf Internasional, mengetahui problematika yang dihadapi dalam pengelolaan kesiswaan, mengetahui tindakan yang ditempuh sekolah dalam mengatasi problematika tersebut, mengetahui faktor penghambat dan faktor pendukung dalam pelaksanaan manajemen kesiswaan pada Sekolah Bertaraf Internasional. Penelitian ini menggunakan metode deskripsi dengan pendekatan kualitatif. pengumpulan data dilakukan dengan mengadakan pengamatan, wawancara dan dokumentasi. Analisis data yang digunakan adalah analisis deskriptif kualitatif. Hasil dalam penelitian ini menunjukan bahwa pelaksanaan manajemen kesiswaan pada sekolah bertaraf Internasional telah terlaksana dengan baik, hal tersebut dapat dilihat dari telah terkelolanya empat aspek manajemen kesiswaan yaitu dari penerimaan peserta didik, ketatausahaan peserta didik, pemberian bimbingan dan penyuluhan dan pencatatan prestasi belajar. Problematika utama yang dihadapi dalam pelaksanaan manajemen kesiswaan yaitu adanya kebijakan pemerintah yang memberikan batasan dalam penggunaan dana, pemerintah pusat kurang mensosialisasikan program Sekolah Bertaraf Internasional.

\section{Student management implementation in international standard school}

This study aims to determine the implementation of student management at international standard schools, know the problems faced in student management, know the actions taken by schools in overcoming these problems, determine the inhibiting factors and supporting factors in the implementation of student management at international standard schools. This study uses a descriptive method with a qualitative approach. Data collection was carried out by conducting observations, interviews and documentation. The data analysis used was descriptive qualitative analysis. The results in this study indicate that the implementation of student management at international standard schools has been carried out well, this can be seen from the management of four aspects of student management, namely from student acceptance, student administration, providing guidance and counseling and recording learning achievement. The main problem faced in the implementation of student management is the existence of government policies that impose limits on the use of funds, the central government does not socialize the International Standard School program. Actions taken to overcome the problem are that schools follow established regulations and then communicate 
directly with the government.

This is an open-access article under the CC-BY-SA license.

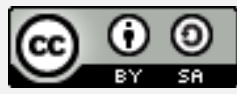

\section{Pendahuluan}

Manajemen kesiswaan merupakan proses mengatur urusan-urusan yang bersangkutan dengan kesiswaan, manajemen ini termasuk salah satu substansi manajemen pendidikan, sebagaimana yang dinyatakan Depdiknas (2007:2) bahwa manajemen kesiswaan menduduki posisi strategis, karena sentral layanan pendidikan, baik dalam latar institusi persekolahan maupun yang berada di luar latar institusi persekolahan, tertuju kepada peserta didik. Semua kegiatan pendidikan, baik yang berkenaan dengan manajemen akademik, layanan pendukung akademik, sumber daya manusia, sumber daya keuangan, sarana prasarana dan hubungan sekolah dengan masyarakat, senantiasa diupayakan agar peserta didik mendapatkan layanan pendidikan yang andal.

Bidang kajian manajemen kesiswaan, meliputi pengaturan aktivitas-aktivitas peserta didik sejak peserta didik masuk ke sekolah hingga peserta didik lulus, baik yang berkenaan dengan peserta didik secara langsung maupun tidak langsung, hal tersebut sebagaimana yang dinyatakan Affinoxy (2009:2) bahwa peserta didik selain sebagai salah satu sumber daya pendidikan, peserta didik juga merupakan masukan (input) utama atau bahan mentah (raw input) bagi proses pendidikan.

Peserta didik menurut Suwarno (2006: 36), yaitu anggota masyarakat yang berusaha menegembangkan potensi diri melalui proses pembelajaran yang tersedia pada jalur, jenjang, dan jenis pendidikan tertentu. Peserta didik perlu dikelola sedemikian rupa sehingga tujuan pendidikan dapat dicapai secara efektif dan efisien. Depdikbud (dalam Affinoxy:2009) menyebutkan empat prinsip dasar dalam pengelolaan kesiswaaan, yaitu: peserta didik harus diperlakukan dengan subyek dan bukan obyek, sehingga harus didorong untuk berperan serta dalam setiap perencanaan dan pengambilan keputusan yang terkait dengan kegiatan mereka; kondisi siswa sangat beragam, ditinjau dari kondisi fisik, kemampuan intelektual, sosial ekonomi, minat, dan diperlukan wahana kegiatan yang beragam, sehingga setiap siswa memiliki wahana untuk berkembang secara optimal; peserta didik hanya akan termotivasi belajar jika mereka menyenangi apa yang diajarkan; pengembangan potensi siswa tidak hanya menyangkut ranah kognitif, tetapi juga ranah afektif, dan psikomotor. .

Pada Undang-undang Nomor 20 Tahun 2003 tertuang upaya peningkatan mutu pendidikan, tepatnya pada pasal 50 ayat 3 yang berbunyi: "Pemerintah dan/atau pemerintah daerah menyelenggarakan sekurang-kurangnya satu satuan pendidikan pada semua jenjang pendidikan, untuk dikembangkan menjadi satuan pendidikan yang bertaraf internasional", Triwiyanto dan Sobri (2010:22), menyimpulkan bahwa tujuan utama pemerintah menyelenggarakan program sekolah bertaraf internasional adalah untuk memperbaiki mutu pendidikan. Keunggulan program Rintisan Sekolah Bertaraf Internasional di antaranya adalah mempunyai sister school di negara lain. Sister school adalah sekolah internasional yang merupakan partner dari sekolah RSBI yang bertujuan untuk memudahkan melakukan akses dan pertukaran informasi pendidikan.

Keberadaan kebijakan sekolah bertaraf internasional memang selama ini tidak sertamerta berjalan mulus, terdapat banyak kritik terhadap kehadiran RSBI. Di antaranya yang dinyatakan Siregar (dalam Kompas, 8/4/2009) menyoroti bahwa pelaksanaan SBI menjadikan kurikulum dan materi pelajaran terkesan tidak terkontrol oleh pemerintah. Selain memakai kurikulum nasional, sekolah-sekolah nasional tersebut juga mengadopsi kurikulum internasional. Bahkan, bahasa pengantarnya yang menggunakan bahasa Inggris 
dalam pembelajaran science. Selain itu, muncul dampak panjang sosial budaya dan nasionalisme pada anak-anak Indonesia. Peserta didik begitu minim pengetahuan sosial dan budaya Indonesia, nilai-nilai historis dan nasionalisme, serta sikap individualisme yang begitu tinggi. Kurikulum sekolah menyiapkan mereka sebagai warga dunia atau sebagai komunitas internasional. Sebaliknya nilai-nilai ke-Indonesiaan tidak ditanamkan.

Martono (dalam Triwiyanto dan Sobri:2010) menyatakan bahwa sekolah bertaraf internasional mengancam potensi lokal. Dampak sosial budaya dan nasionalisme seperti diungkapkan di atas bukan akan terjadi sekarang, melainkan pada dampak panjang. Hal ini menjadi sulit sekali memprediksi apa yang akan terjadi pada peserta didik sekian puluh tahun ke depan, terutama yang belajar di sekolah-sekolah bertaraf internasional sekarang.

Paparan di atas memperlihatkan bahwa masih terdapat sisi-sisi lemah di balik keunggulan-keunggulan dalam penyelenggaran sekolah bertaraf internasional, dan tentu saja memiliki implikasi terhadap pengelolaan sekolah. Hal inilah yang menarik penulis untuk melakukan kajian tentang manajemen kesiswaan pada sekolah bertaraf internasional. Adapun tujuan yang ingin dicapai dalam penelitian ini yaitu mengetahui pelaksanaan manajemen kesiswaan yang diterapkan pada Sekolah Bertaraf Internasional , mengetahui problematika dalam pengelolaan kesiswaan, mengetahui tindakan yang ditempuh sekolah dalam mengatasi problematika tersebut; mengetahui faktor penghambat dan faktor pendudkung dalam pelaksanaan manajemen kesiswaan pada Sekolah Bertaraf Internasional.

Adapun Manfaat dari penelitian ini adalah menjadi refrensi dan bahan kajian terkait manajemen kesiswaan guna meningkatkan efektivitas penyelenggaraan manajemen sekolah dalam meningkatkan kualitas pendidikan sekolah. Adapun bagi Direktorat Pendidikan Nasional, apabila penerapan RSBI bagus, maka dapat dijadikan masukan untuk pengalihan status bagi sekolah yang belum berpredikat Internasional menjadi sekolah yang berpredikat Internasional.

\section{Metode}

Penelitian ini merupakan penelitian melalui pendekatan kualitatif, metode pengumpulan data yang digunakan adalah metode wawancara sebagai teknik utamanya. Wawancara yang digunakan dalam penelitian ini adalah metode wawancara terstruktur, sebagaimana yang dinyatakan (Idrus 2009:107), kegiatan wawancara terstruktur ini biasanya dilakukan oleh peneliti dengan cara mempersiapkan bahan pertanyaan terlebih dahulu, sekilas langkah ini hampir sama dengan angket yang dibacakan hanya saja dalam wawancara ini peneliti harus mampu mengembangkan kemampuannya menggali informasi dari informasi.

Selain itu, dilakukan juga observasi partisipatif, Metode ini digunakan untuk melihat/mengamati secara langsung keadaan di lapangan agar peneliti memperoleh gambaran yang lebih luas tentang permasalahan yang diteliti, metode dokumentasi sebagai teknik pendukungnya. digunakan untuk memperoleh data yang terkait dengan permasalahan yang sedang diteliti, yaitu berupa arsip penting yang ada pada lembaga/sekolah tersebut seperti struktur organisai sekolah, visi dan misi sekolah tersebut. Untuk analisis data kualitatif ini akan digunakan model interaktif yang terdiri dari tiga pokok utama, yaitu reduksi data, penyajian data; dan penarikan kesimpulan/verifikasi.

\section{Hasil dan Pembahasan}

\section{Tinjauan Manajemen Kesiswaan}

Hasil dan Pembahasan dapat disajikan dalam subbab. Membahas secara jelas pokok bahasan sesuai dengan masalah, tujuan penelitian, dan teori yang digunakan.

Dari beberapa definisi manajemen kesiswaan yang ada dapat diketahui bahwa manajemen kesiswaan sangat diperlukan dalam pendidikan, karena dengan adanya 
manajemen kesiswaan, segala urusan dan persoalan yang berkaitan dengan peserta didik dapat diatasi dengan baik.

Arikunto dan Yuliana (2008:57), mengelompokan ruang lingkup pengelolaan dalam bidang kesiswaan, yaitu menjadi 4 kelompok, (a) penerimaan siswa; (b) ketatausahaan siswa; (c) pencatatan bimbingan dan penyuluhan; (d) pencatatan prestasi belajar.

Berdasar pada hal di atas, maka perlunya ada tujuan yang jelas dalam mengelola kesiswaan untuk menata proses kesiswaan mulai dari perekrutan, mengikuti pembelajaran sampai dengan lulus sesuai dengan tujuan institusional agar dapat berlangsung secara efektif dan efisien karena di samping itu juga, manajemen kesiswaan itu sendiri memiliki tujuan untuk mengatur kegiatan-kegiatan dalam bidang kesiswaan agar proses pembelajaran yang dilaksanakan di suatu sekolah dapat berjalan dengan lancar, tertib dan teratur sedemikian rupa sehingga apa yang menjadi tujuan utama dari suatu program pembelajaran di sekolah dapat tercapai secara optimal.

Adapun fungsi manajemen kesiswaan secara khusus dirumuskan sebagai berikut: fungsi yang berkenaan dengan pengembangan individualitas peserta didik, fungsi yang berkenaan dengan pengembangan, fungsi sosial peserta didik, fungsi yang berkenaan dengan penyaluran aspirasi dan harapan peserta didik, fungsi yang berkenaan dengan pemenuhan kebutuhan dan kesejahteraan peserta.

Prinsip dalam manajemen kesiswaan mengandung arti bahwa dalam rangka memanaj peserta didik, prinsip-prinsip yang disebutkan di bawah ini haruslah selalu dipegang dan dipedomani. Adapun prinsip-prinsip manajemen peserta didik menurut Depdiknas (2007:12) adalah manajemen peserta didik dipandang sebagai bagian dari keseluruhan manajemen sekolah, maka dari itu, ia harus mempunyai tujuan yang sama dan atau mendukung terhadap tujuan manajemen secara keseluruhan. Ambisi sektoral manajemen peserta didik tetap ditempatkan dalam kerangka manajemen sekolah. Ia tidak boleh ditempatkan di luar sistem manajemen sekolah

Segala bentuk kegiatan manajemen peserta didik haruslah mengemban misi pendidikan dalam rangka mendidik para peserta didik. Segala bentuk kegiatan, baik itu ringan, berat, disukai atau tidak disukai oleh peserta didik, haruslah diarahkan untuk mendidik peserta didik dan bukan untuk yang lainnya, kegiatan-kegiatan manajemen peserta didik haruslah diupayakan untuk mempersatukan peserta didik yang mempunyai aneka ragam latar belakang dan punya banyak perbedaan. Perbedaan-perbedaan yang ada pada peserta didik, tidak diarahkan bagi munculnya konflik di antara mereka melainkan justru mempersatukan dan saling memahami dan menghargai

Kegiatan manajemen peserta didik haruslah dipandang sebagai upaya pengaturan terhadap pembimbingan peserta didik, maka dari itu, dalam membimbing, haruslah terdapat ketersediaan dari pihak yang dibimbing. Ialah peserta didik sendiri. Tidak mungkin pembimbingan demikian akan terlaksana dengan baik manakala terdapat keengganan dari peserta didik sendiri.

Kegiatan manajemen peserta didik haruslah mendorong dan memacu kemandirian peserta didik. Prinsip kemandirian demikian akan bermanfaat bagi peserta didik tidak hanya ketika di sekolah, melainkan juga ketika sudah terjun ke masyarakat, hal tersebut mengandung arti bahwa ketergantungan peserta didik haruslah sedikit demi sedikit dihilangkan melalui kegiatan-kegiatan manajemen peserta didik. Apa yang diberikan kepada peserta didik dan yang selalu diupayakan oleh kegiatan manajemen peserta didik haruslah fungsional bagi kehidupan peserta didik baik di sekolah lebih-lebih di masa depan.

\section{Rintisan Sekolah Bertaraf Internasional}

Sekolah bertaraf Internasional atau SBI merupakan sekolah untuk anak-anak Indonesia yang diselenggarakan dengan kurikulum lokal tetapi bertaraf internasional. Triwiyanto dan Sobri (2010:14), mengemukakan bahwa sekolah bertaraf internasional merupakan usaha 
pemerintah untuk memperbaiki mutu pendidikan dengan perbaikan-perbaikan pada pengelolaan input peserta didik, kurikulum, pendidik dan tenaga kependidikan, sarana dan prasarana, dana, manajemen dan lingkungan. Pengembangan SBI di Indonesia didasari oleh Undangundang No. 20 Tahun 2003 tentang Sistem Pendidikan Nasional Pasal 50 Ayat 3. Dalam ketentuan ini, pemerintah didorong untuk mengembangkan satuan pendidikan yang bertaraf internasional.

Adapun kriteria dasar yang menjadi syarat sebuah sekolah menjadi sekolah bertaraf internasional menurut Depdiknas 2005-2009 (dalam Triwiyanto dan Sobri: 2010) yaitu peningkatan mutu sekolah harus setara dengan sekolah dari lembaga internasional, guru dan kepala sekolah harus memperoleh sertifikasi dan atau lisensi internasional, peningkatan mutu sekolah harus dilandasi suatu rencana yang bottom up yaitu partisipasi masyarakat, pemda, selama proses peningkatan mutu untuk menjamin keberlangsungan dan melibatkan instansi profesional dan bermitra dengan sekolah luar negeri agar lulusannya dapat diterima di dalam dan luar negeri.

Adapun kriteria dasar yang menjadi syarat sebuah sekolah menjadi sekolah bertaraf internasional menurut Depdiknas 2005-2009 (dalam Triwiyanto dan Sobri: 2010) yaitu peningkatan mutu sekolah harus setara dengan sekolah dari lembaga internasional, guru dan kepala sekolah harus memperoleh sertifikasi dan atau lisensi internasional, peningkatan mutu sekolah harus dilandasi suatu rencana yang bottom up yaitu partisipasi masyarakat, pemda, selama proses peningkatan mutu untuk menjamin keberlangsungan dan melibatkan instansi profesional dan bermitra dengan sekolah luar negeri agar lulusannya dapat diterima di dalam dan luar negeri. Dalam pengembangan Sekolah Bertaraf Internasional (SBI) diharapkan ada ciri-ciri yang semakin menguat sebagai pembeda dari sekolah lain. Ciri-ciri tersebut meliputi faktor fisik, intelektual, sosial dan spritual.

Ruang lingkup pengelolaan sekolah bertaraf internasional menurut Triwiyanto dan Sobri, (2010: 24-27), dibagi menjadi beberapa lingkup dan komponen yaitu:

Akreditasi, minimal predikat A dari Badan Akreditasi Nasional Sekolah/Madrasah. Sekolah bertaraf internasional setiap saat selalu menunjukan keunggulan kinerja yang sangat baik dan sekaligus, hasil akreditasi, baik dari badan akreditasi sekolah pada salah satu negara anggota OECD dan/atau negara maju lainnya yang mempunyai keunggulan tertentu dalam bidang pendidikan.

Kurikulum, minimal menerapkan KTSP, menerapkan sistem satuan kredit semester di SMA/SMK/MA/MAK, memenuhi standar isi, kompetensi, berbasisi teknologi informasi dan komunikasi, muatan mata pelajaran setara atau lebih tinggi dari muatan yang sama pada sekolah unggul dari salah satu negara-negara maju lainnya yang memounyai keunggulan tertentu dalam bidang pendidikan dan menerapkan stndar kelulusan sekolah/madrasah yang lebih tinggi dari standar kompetensi lulusan

Proses Pembelajaran, minimal memenuhi standar proses, proses pembelajaran disesuaikan dengan bakat, minat dan perkembangan fisik serta fsikologis peserta didik, proses pembelajaran menjadi teladan bagi sekolah lainnya dalam pengembangan akhlak mulia, budi pekerti luhur, kepribadian unggul, kepemimpinan, jiwa wirausaha, jiwa patriot dan jiwa inovator, diperkaya model proses pembelajaran sekolah unggul dari negara maju lainnya dan menerapkan pembelajaran berbasis TIK;

Tenaga Kependidikan, minimal memenuhi standar kepala sekolah, pendidikan minimal S2 dari perguruan tinggi yang program studinya berakreditasi A dan telah menempuh pelaktihan kepala sekolah dari lembaga pelatihan kepala sekolah yang diakui oleh Pemerintah, mampu berbahasa Inggris secara aktif; dan bervisi Internasional, memiliki kompetensi manajerial, serta jiwa kepemimpinan, dan jiwa wirausaha yang kuat.

Sarana dan Prasarana, minimal memenuhi standar sarana dan prasarana, setiap ruang kelas dilengkapi dengan sarana pembelajaran berbasis TIK, perpustakaan dilengkapi dengan sarana digital yang memberikan akses ke sumber pembelajaran berbasis TIK di seluruh dunia 
dan dilengkapi dengan ruang multimedia, ruang unjuk seni budaya, fasilitas olahraga, klinik dan lain sebagainya.

Pengelolaan, minimal memenuhi standar pengelolaan, meraih sertifikat ISO 9901 versi 2000 atau sesudahnya ISO 14000, merupakan sekolah multikultural, menjalin hubungan "sister school" dengan sekolah bertaraf internasional di luar negeri, bebas narkoba dan rokok, bebas kekerasan (bullying), menerapkan sistem kesetaraan gander dalam segala aspek pengelolaan sekolah dan meraih medali tingkat internasional pada berbagai kompetisi sains: matematika, teknologi seni, dan olahraga. Sementara, pembiayaan memiliki standar, yaitu 1) minimal memenuhi standar pembiayaan; dan 2) menerapkan model pembiayaan yang efisien untuk mencapai berbagai target indikator kunci tambahan.

\section{Karakteristik Manajemen Pemasaran di STIT Madani Yogyakarta}

Pelaksanaan manajemen kesiswaan secara umum telah terlaksana meskipun belum maksimal, hal tersebut dapat diketahui dari tugas-tugas kesiswaan yang telah terlaksana seperti dalam penerimaan peserta didik baru, pendataan siswa yang nantinya dimasukan ke database sekolah. Keberhasilan pelaksanaan manajemen kesiswaan ini tidak terlepas dari peran kepemimpinan kepala sekolah sebagai pemimpin sekolah dan bidang kesiswaan sebagai yang diberi tugas untuk mengatur kesiswaan, selain itu juga keberhasilan manajemen kesiswaan ini didukung oleh para guru, tenaga administrasi dan tenaga pendukung lainnya, kegiatan- kegiatan yang dilakukan SBI dalam pelaksanakan manajemen kesiswaan secara garis besarnya dibagi menjadi empat kelompok yaitu masalah penerimaan peserta didik baru, ketata usahaan siswa, program bimbingan dan penyuluhan dan pencatatan prestasi belajar. untuk pemaparan aspek-aspek dari manajemen kesiswaan pada sekolah Bertaraf Internasional sebagai berikut :

a. Penerimaan Peserta Didik Baru: proses penerimaan peserta didik baru pada sekolah bertaraf Internasional melalui dua proses penerimaan, yaitu dengan mengikuti peraturan pemerintah dan sistem RTO. Berdasarkan data yang diperoleh dari persyaratan penerimaan peserta didik baru pada sekolah SBI dibagi menjadi beberapa quota yaitu:

1) Calon siswa baru Keluarga Miskin mendapat kuota maksimum $25 \%$ dari daya tampung seluruh SMP Negeri.

2) Calon siswa Non KMS penduduk dalam daerah (kota Yogyakarta) mendapat kuota minimal $55 \%$ dari daya tampung keseluruhan.

3) Calon siswa Non KMS peduduk luar daerah mendapat kuota maksimal $20 \%$.

b. Ketata Usahaan Peserta Didik: kaitannya dalam administrasi kesiswaan, tugas tata usaha adalah:pendataan, setelah pendataan itu terkumpul maka dimasukan di database, yang nantinya berkaitan dengan buku induk dan pembagian kelas yang menjadi wewenang kurikulum. ketatausahaan peserta didik juga bertugas membuat buku-buku atau catatancatan sebagai berikut 1) buku induk yang dipegang oleh kesiswaan, 2) buku kleper, 3) buku mutasi, 4)buku daftar nilai dan 5) pendaftaran peserta UAN

c. Aspek ketiga dari manajemen kesiswaan adalah pemberian bimbingan dan penyuluhan. Bimbingan pendidikan adalah pertolongan yang diberikan terhadap peserta didik yang mengalami kesulitan belajar dan kesukaran-kesukaran lain yang timbul dalam interaksinya dengan pendidik termasuk guru dan orang tua. berbagai bentuk kegiatan, bimbingan dan penyuluhan ini ditugaskan sekolah kepada BK sebagai tangan kanannya dari bidang kesiswaan. Bimbinganbimbingan yang ada di SBI adalah bimbingan khusus belajar, bimbinganbimbingan khusus yang diberikan sekolah yaitu program afternoon class yaitu penambahan jam pelajaran di luar jam sekolah.

d. Pencatatan Prestasi Belajar. Pencatatan prestasi belajar di SBI sudah canggih, pencatatan dan penyetoran nilai yang dilakukan oleh para guru ke wali kelas yaitu dengan menggunakan impra net. System ini otomatis memuat nilai-nilai dan catatan-catatan peserta didik dari guru yang bersangkutan akan masuk langsung pada wali kelas. 


\section{Problematika Pelaksanaan Manajemen Kesiswaan}

Berdasarkan analisis penulis, problematika yang dihadapi pada sekolah bertaraf internasional pada umumnya merupakan faktor umum yang secara signifikan tidak berdampak besar, karena sampai saat ini sekolah masih dapat mengatasi problem-problem tersebut.

Adapun faktor-faktor tersebut yaitu problematika yang paling besar dalam pelaksanaan manejemen kesiswan pada SBI, pertama adalah kebijakan dari pemerintah yang terlalu dibatasi dalam penggunaan dana. Dana ada, tetapi dibatasi dalam penggunaannya, itu sangat menghambat pelaksanaan manajemen kesiswaan, sehingga setiap ada kegiatan pihak sekolah (kesiswaan) yang berkaitan dengan program kesiswaan, itu harus mengajukan proposal dan minta persetujuan dari Pemerintahan Walikota

Masalah yang kedua adalah masa yang timbul dari orang tua atau wali murid yang over protektive, sehingga menganggap pihak sekolah terlalu mengekang peserta didik, selalu mengatur kebebasan peserta didik, padahal tujuan sekolah baik yaitu agar sesuai dengan tujuan pendidikan.

Masalah ketiga adalah timbul dari kenakalan dari peserta didik, yang melanggar tata tertib seperti terlambat datang ke sekolah, berkelahi, mencuri, terjadi peserta didik yang merasa diri pintar sehingga terkadang mempolitisir ketika ditegur oleh guru. Keempat adanya kesulitan dalam pendataan peserta didik baru, yang mana sering kali mengalami kesulitan untuk memasukan data peserta didik di database, terkendala dalam pengumpulan datanya yang lama.sedangkan masalah terakhir adalah banyaknya permintaan dari peserta didik untuk melaksanakan program-program, tetapi terbentur pada dana yang dibatasi.

\section{Tindakan yang ditempuh dalam mengatasi problematika pelaksanaan}

\section{manajemen kesiswaan pada Sekolah Bertaraf Internasional}

Hasil analisis dari tindakan yang telah ditempuh SBI, maka tindakan-tindakan yang ditempuh untuk mengatasi problematika yang ada dalam pelaksanaan manajemen kesiswaan tersebut yaitu dalam mengatasi kebijakan yang dibuat pemerintah kota, pihak sekolah tidak dapat melakukan apa-apa, kecuali hanya bisa mengikuti peraturan yang telah ditetapkan karena itu peraturan mutlak yang harus dilaksanakan. Dalam pengumpulan data peserta didik baru, pihak sekolah khususnya TU berperan proaktif dengan cara menanyakan dan menagih secara terus-menerus kepada wali kelas seabagai yang diamanahi mengurus peserta didik di kelas, supaya data peserta didik baru cepat terkumpul dan dapat dimasukan ke data base dengan cepat.

Terkait dengan kesulitan dalam pengumpulan data yang dilakukan oleh TU, itu sebenarnaya tidak menjadi satu penghambat utama dalam pengelolaannya, karena ketata usahaan sendiri dapat mengatasi permasalahan tersebut.

Dalam mengatasi anak yang nakal seperti terlambat datang ke sekolah, mencuri, berkelahi itu diingatkan, ditegur dan diberlakukannya point bagi peserta didik yang melanggar peraturan sekolah, adapun mengatasi permintaan dari peserta didik, maka pihak sekolah sebisa mungkin meminimalisir pengeluaran dana, karena meskipun dana ada tetapi tidak diijinkan oleh pemerintahan walikota, maka tetap tidak dapat dilaksanakan.

Mengatasi orang tua yang over protektive, sekolah memberikan pengertianpengertian atau berkonsultasi antara pihak sekolah dan wali murid meskipun terkadang orang tua tidak bisa menerima. 


\section{Faktor Penghambat Pelaksanaan Manajemen Kesiswaan}

Tiga faktor yang dapat menghambat dalam pelaksanaan manajemen kesiswaan pada sekolah bertaraf internasional yaitu faktor keuangan/financial, faktor dari peserta didik/Students, dan masih terkendalanya di sistem layanan IT yang belum maksimal/ system.

\section{Faktor Pendukung Pelaksanaan Manajemen Kesiswaan}

Setelah dianalisis terkait dengan faktor-faktor penghambat ada juga faktor-faktor pendukung dalam pelaksanaan manajemen kesiswaan pada sekolah bertaraf internasional yaitu;

a. Faktor yang pertama adalah faktor dari orangtua murid (wali murid) yang care dan relasi yang banyak sehingga mudah diajak kerjasama, orang tua peserta didik yang peduli serta relasi yang banyak

b. Faktor peserta didik, adanya kemauan dari peserta didik yang tinggi dalam pembelajaran, peserta didik yang rata-rata memiliki IQ di atas rata-rata dari sekolah lain, komitmen guru yang tinggi dalam mewujudkan peserta didik yang sukses dan berhasil dalam mewujudkan tujuan pembelajaran.

c. Faktor arana dan prasarana yang lengkap seperti buku-buku yang banyak sehingga ini menjadi salah satu faktor pendukung dalam pelaksanaan manajemen kesiswaan pada sekolah bertaraf Internasional, dengan adanya sarana dan prasarana lengkap, maka ini menjadi catatan positif bagi sekolah bertaraf Internasional dan juga sebagai penunjang belajar peserta didik sehingga dapat memudahkan proses pembelajaran dan keperluan di luar pembelajaran yang ada di sekolah bertaraf Internasional.

d. Faktor kepemimpinan tegas dan disiplin kepala sekolah yang menjadi faktor utama keberhasilan berjalannya manajemen kesiswaan dengan baik pada sekolah bertaraf Internasional.

\section{Simpulan}

Susunlah simpulan dengan kalimat ringkas sebagai jawaban dari pertanyaan penelitian atau sebagai pembuktian dari hipotesis penelitian. Simpulan idealnya tergambar hubungan antara pertanyaan penelitian, tujuan, hasil dan pembahasan.

Pelaksanaan manajemen kesiswaan pada sekolah bertaraf Internasional di telah terlaksana dengan baik walaupun masih belum maksimal, hal tersebut dapat dilihat dari pengelolaan aspek-aspek manajemen kesiswaan yang telah terkelola dengan cukup baik, hal tersebut terbukti bahwa sekolah bertaraf internasional yang ada telah melaksanakan sistem manejemen mutu ISO, di samping itu juga sekolah dapat menghasilkan out put yang berkualitas dan berprestasi sehingga dapat menjadi kebanggaan dan salah satu kelebihan dari sekolah atau lembaga yang ada.

Problematika yang dihadapi dalam pelaksanaan manajemen kesiswaan yaitu adalah adanya kebijakan dari pemerintah yang terlalu dibatasi dalam penggunaan dana, orang tua atau wali murid yang over protektive, kenakalan dari peserta didik yang melanggar tata tertib, adanya kebijakan khusus terkait peserta didik dari kalangan KMS, kesulitan dalam pendataan peserta didik baru, banyaknya permintaan dari peserta didik untuk melaksanakan program-program, tetapi terbentur pada dana yang dibatasi.

Adapun tindakan yang ditempuh dalam mengatasi problematika pelaksanaan manajemen kesiswaan pada sekolah bertaraf Internasional adalah sebagai berikut, dalam mengatasi kebijakan Pemerintah, sekolah tidak dapat melakukan apa-apa kecuali hanya mengikuti peraturan yang ditetapkan Pemerintah, terkait masalah administrasi pihak sekolah khususnya TU berperan proaktif dengan cara menanyakan dan menagih secara terusmenerus kepada wali kelas.

Sekolah memberikan perhatian lebih, mengatasi kenakalan peserta didik ramai di kelas 
dan melanggar peraturan, pihak sekolah atau guru mengingatkan dengan jalan ditegur dan diberlakukannya point bagi peserta didik yang melanggar peraturan sekolah, mengatasi banyak permintaan dari peserta didik, pihak sekolah sebisa mungkin meminimalisir pengeluaran dana, mengatasi orang tua yang over protective sekolah memberikan pengertian-pengertian atau berkonsultasi antara pihak sekolah dan orang tua atau wali dari peserta didik.

Faktor pendukung dalam pelaksanaan manajemen kesiswaan pada sekolah bertaraf Internasional yaitu adanya faktor dari orang tua (wali peserta didik) yang care dan memiliki relasi yang banyak, faktor sarana dan prasarana yang lengkap, faktor dari kepemimpinan kepala sekolah yang disiplin.

\section{Daftar Pustaka}

Affinoxy, 2005. Manajemen Penelitian. Jakarta: Rineka Cipta

Arikunto, S dan Yuliana, L. 2008. Mananajemen Pendidikan. Yogyakarta: Aditya Media

Departemen Pendidikan Nasional. 2007. Manajemen Kesiswaan (Peserta Didik): Jakarta

Idrus, Muhammad. 2009, Metode Penelitian Ilmu Sosial, Jakarta: Erlangga.

Suwarno, Wiji. 2006. Dasar-Dasar Ilmu Pendidikan. Yogyakarta: Ar-Ruzz Media.

Triwiyanto, Teguh dan Sobri, Yusuf, Ahmad. 2010. Panduan Mengelola Sekolah Bertaraf Internasional. Yogyakarta: Ar-Ruzz Media. 